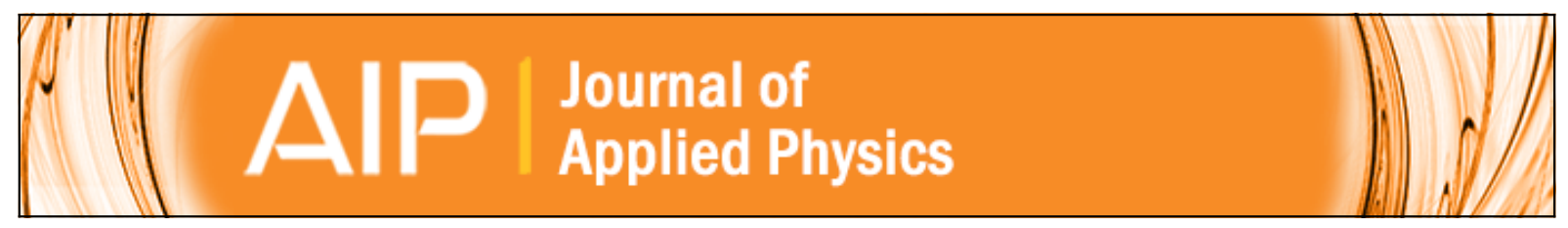

Network structure and thermal stability study of high temperature seal glass

K. Lu and M. K. Mahapatra

Citation: Journal of Applied Physics 104, 074910 (2008); doi: 10.1063/1.2979323

View online: http://dx.doi.org/10.1063/1.2979323

View Table of Contents: http://scitation.aip.org/content/aip/journal/jap/104/7?ver=pdfcov

Published by the AIP Publishing

Articles you may be interested in

Synthesis and structural studies of multi-component strontium zinc silicate glass-ceramics

AIP Conf. Proc. 1512, 568 (2013); 10.1063/1.4791164

Structural studies of some glass/glass-ceramics sealants using NMR and XRD

AIP Conf. Proc. 1447, 45 (2012); 10.1063/1.4709877

The development of a rapid quenching device for the study of the dependence of glass structure on fictive temperature

Rev. Sci. Instrum. 77, 013901 (2006); 10.1063/1.2162751

Raman spectroscopic studies of $\mathrm{TeO} 2$ - $\mathrm{BaO}$ - SrO - Nb 2 O 5 glasses: Structure-property correlations J. Appl. Phys. 96, 2437 (2004); 10.1063/1.1772890

Differential scanning calorimetry, $\mathrm{x}$-ray diffraction and $19 \mathrm{~F}$ nuclear magnetic resonance investigations of the crystallization of InF 3 -based glasses

J. Chem. Phys. 109, 2432 (1998); 10.1063/1.476812

MIT LINCOLN LABORATORY CAREERS

Discover the satisfaction of innovation and service to the nation
- Space Control

- Air \& Missile Defense

- Communications Systems \& Cyber Security

- Intelligence, Surveillance and

Reconnaissance Systems

\section{LINCOLN LABORATORY}

MassachusetTS Institute OF TeChNOLOGY

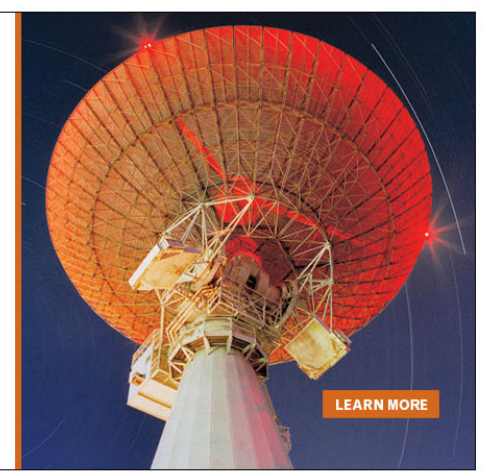




\title{
Network structure and thermal stability study of high temperature seal glass
}

\author{
K. Lu ${ }^{\text {a) }}$ and M. K. Mahapatra ${ }^{\text {b) }}$ \\ Department of Materials Science and Engineering, Virginia Polytechnic Institute and State University, \\ Blacksburg, Virginia 24061, USA
}

(Received 10 June 2008; accepted 14 July 2008; published online 6 October 2008)

\begin{abstract}
High temperature seal glass has stringent requirement on glass thermal stability, which is dictated by glass network structures. In this study, a $\mathrm{SrO}-\mathrm{La}_{2} \mathrm{O}_{3}-\mathrm{Al}_{2} \mathrm{O}_{3}-\mathrm{B}_{2} \mathrm{O}_{3}-\mathrm{SiO}_{2}$ based glass system was studied using nuclear magnetic resonance, Raman spectroscopy, and x-ray diffraction for solid oxide cell application purpose. Glass structural unit neighboring environment and local ordering were evaluated. Glass network connectivity as well as silicon and boron glass former coordination were calculated for different $\mathrm{B}_{2} \mathrm{O}_{3}: \mathrm{SiO}_{2}$ ratios. Thermal stability of the borosilicate glasses was studied after thermal treatment at $850{ }^{\circ} \mathrm{C}$. The study shows that high $\mathrm{B}_{2} \mathrm{O}_{3}$ content induces $\mathrm{BO}_{4}$ and $\mathrm{SiO}_{4}$ structural unit ordering, increases glass localized inhomogeneity, decreases glass network connectivity, and causes devitrification. Glass modifiers interact with either silicon- or boron-containing structural units and form different devitrified phases at different $\mathrm{B}_{2} \mathrm{O}_{3}: \mathrm{SiO}_{2}$ ratios. $\mathrm{B}_{2} \mathrm{O}_{3}$-free glass shows the best thermal stability among the studied compositions, remaining stable after thermal treatment for $200 \mathrm{~h}$ at $850^{\circ} \mathrm{C}$. () 2008 American Institute of Physics. [DOI: $10.1063 / 1.2979323$ ]
\end{abstract}

\section{INTRODUCTION}

Glass is the most preferred candidate as planar solid oxide fuel and electrolyzer cell seals. ${ }^{1}$ To be used as a seal, one of the most important and challenging criteria is thermal stability at solid oxide cell operating temperature for a long time $(>50000 \mathrm{~h})$. A new glass based on $\mathrm{SrO}-\mathrm{La}_{2} \mathrm{O}_{3}-\mathrm{Al}_{2} \mathrm{O}_{3}-\mathrm{B}_{2} \mathrm{O}_{3}-\mathrm{SiO}_{2}$ (SABS) system has been reported to demonstrate excellent thermal properties. ${ }^{2}$ However, $\mathrm{La}_{2} \mathrm{O}_{3}$ and $\mathrm{B}_{2} \mathrm{O}_{3}$ degrade the thermophysical stability of the SABS glass system and contribute to devitrification by forming $\mathrm{LaBO}_{3}{ }^{3,4}$ Also, $\mathrm{B}_{2} \mathrm{O}_{3}$ may evaporate in the form of volatile $\mathrm{HBO}_{2}$ and $\mathrm{B}(\mathrm{OH})_{3}$ species in the presence of water steam at cell operating temperatures. ${ }^{5,6}$ There is a need to understand the SABS glass network structure in order to improve the thermal stability of the glass system.

The key aspects regarding glass structure are network connectivity and homogeneity, which directly affect the thermal stability of a glass. Connectivity in a glass structure is described by the number and arrangement of bridging and nonbridging oxygen atoms, which link the structural units to their neighbors. Glass homogeneity is directly related to the distribution of different structural units and modifiers. If there is heterogeneity, such as structural unit ordering or distribution preference in a glass, even if in small localized regions, glass can devitrify easily. ${ }^{7}$

Nuclear magnetic resonance (NMR) spectroscopy has been used to analyze glass structure differences. The temporal evolution of the coordination environments of boron atoms in borosilicate glasses was studied. The temperature dependence of boron speciation was found to be the most

\footnotetext{
${ }^{\text {a) }}$ Author to whom correspondence should be addressed. Electronic address: klu@vt.edu. Tel.: +1 540231 3225. FAX: +1 5402318919.

${ }^{b)}$ Electronic mail: mkmanoj@vt.edu.
}

important source for the production of configurational entropy in these glasses, signifying a direct link between structure, configurational entropy, and viscous flow. ${ }^{8}$ The structure of $\mathrm{BeO}-\mathrm{SiO}_{2}$ glasses with up to $20 \mathrm{~mol} \% \mathrm{BeO}$ was studied with ${ }^{9} \mathrm{Be}$ and ${ }^{29} \mathrm{Si}$ NMR spectroscopic techniques. The NMR results showed nanoclusters of corner-shared $\mathrm{BeO}_{4}$ and highly strained corner-shared $\mathrm{SiO}_{4}$ network. ${ }^{9}$ Distributions of aluminum among the structural units in $\mathrm{CaO}-\mathrm{Al}_{2} \mathrm{O}_{3}-\mathrm{SiO}_{2}$ and $\mathrm{MgO}-\mathrm{Al}_{2} \mathrm{O}_{3}-\mathrm{SiO}_{2}$ glasses were investigated by ${ }^{29} \mathrm{Si}$ and ${ }^{27} \mathrm{Al}$ magic angle spinning (MAS) NMR. Taking the convention that the silicate units with four bridging oxygen atoms, three bridging oxygen atoms, two bridging oxygen atoms, one bridging oxygen atom, and zero bridging oxygen atom are denoted as $Q^{4}, Q^{3}, Q^{2}, Q^{1}$, and $Q^{0}$, respectively. The results indicated that aluminum is largely in $Q^{4}$ sites, except in Al-rich glasses where it is also in $Q^{3}$ sites. ${ }^{10}{ }^{17} \mathrm{O}$ enriched calcium and potassium aluminoborosilicate glasses were studied by ${ }^{11} \mathrm{~B},{ }^{27} \mathrm{Al}$, and ${ }^{17} \mathrm{O}$ NMR.${ }^{11}$ Dramatic differences in boron and oxygen speciation demonstrate a large effect of the modifier cations on glass former mixing behavior and stabilization of nonbridging oxygen atoms.

Raman spectroscopy is another important technique that can identify the structural units present in a glass. ${ }^{12-14}$ For chalcogenide glasses, Raman scattering played a pivotal role in elucidating the molecular structures and identifying domains of intermediate phases. ${ }^{15}$ Raman spectra from $\mathrm{Na}_{2} \mathrm{O}-\mathrm{CaO}-\mathrm{MgO}-\mathrm{Al}_{2} \mathrm{O}_{3}-\mathrm{SiO}_{2}$ system were interpreted in terms of structural alteration as the composition was altered from the binary end members to more complicated glasses. ${ }^{16}$ Addition of $\mathrm{CaO}$ and $\mathrm{MgO}$ to $\mathrm{Na}_{2} \mathrm{O}-\mathrm{SiO}_{2}$ glasses acted only to increase the disorder of the network slightly. Addition of $\mathrm{Al}_{2} \mathrm{O}_{3}$ greatly modified the network. In the $\mathrm{Na}_{2} \mathrm{O} \cdot R_{2} \mathrm{O}_{3} \cdot \mathrm{SiO}_{2}$ $(R=\mathrm{Al}, \mathrm{B})$ system, Raman spectroscopy showed that $\mathrm{B}_{2} \mathrm{O}_{3}$ 
induces destruction of the $Q^{3}$ species and the creation of highly charged $Q^{2}$ and $Q^{1}$ species, as well as fully connected $Q^{4}$ silicate units. ${ }^{17}$

The current study is focused on understanding the network structure and thermal stability of the SABS glass system. To examine the SABS glass structural evolution with $\mathrm{B}_{2} \mathrm{O}_{3}: \mathrm{SiO}_{2}$ ratio change, MAS NMR, and Raman spectroscopy studies have been carried out. Structural evolution data obtained from NMR and Raman spectroscopy, two complementary methods for giving detailed information about borosilicate glass structure, provide the best knowledge about the devitrification resistance of the studied SABS glass system. NMR gives access to the $\mathrm{BO}_{3} / \mathrm{BO}_{4}$ ratio and to the identification of the different structural unit environment, whereas Raman spectroscopy gives information on glass structural unit types, ordering, and distribution. Glass network connectivity and coordination have been calculated for different SABS glasses. To examine the SABS glass thermal stability at high temperatures, x-ray diffraction (XRD) study has been carried out for the SABS glasses thermally treated at $850{ }^{\circ} \mathrm{C}$. The evolution of devitrified phases versus the SABS glass compositions is discussed. The correlation between the glass network structure and thermal stability is established.

\section{EXPERIMENTAL PROCEDURE}

\section{A. Glass preparation}

SABS glass samples were prepared with conventional quenching method. $\mathrm{SrCO}_{3}(99.9 \%$, Sigma Aldrich, St. Louis, MO), $\mathrm{La}_{2} \mathrm{O}_{3}(99.98 \%), \mathrm{Al}_{2} \mathrm{O}_{3}(99.95 \%), \mathrm{B}_{2} \mathrm{O}_{3}(99.98 \%)$, and $\mathrm{SiO}_{2}(99.8 \%$ ) (all oxides from Alfa Aesar, Ward Hill, MA) at designed ratios were mixed in a ball mill for overnight. The mixed powders were heated in a platinum crucible in a box furnace (Lindberg, Model 51314, Watertown, WI) to $1100{ }^{\circ} \mathrm{C}$ and kept there for $1 \mathrm{~h}$ for $\mathrm{SrCO}_{3}$ to decompose. After that, the mixture was heated to $1400{ }^{\circ} \mathrm{C}$ for $4 \mathrm{~h}$. The heating rate was $10{ }^{\circ} \mathrm{C} \mathrm{min}{ }^{-1}$. The molten glass was quenched into a graphite mold.

All the glass compositions had $40 \mathrm{~mol} \%$ of $\mathrm{SrO}$, $\mathrm{La}_{2} \mathrm{O}_{3}$, and $\mathrm{Al}_{2} \mathrm{O}_{3}$ at fixed $\mathrm{SrO}: \mathrm{La}_{2} \mathrm{O}_{3}: \mathrm{Al}_{2} \mathrm{O}_{3}$ ratios. The total amount of $\mathrm{B}_{2} \mathrm{O}_{3}$ and $\mathrm{SiO}_{2}$ was $60 \mathrm{~mol} \%$ and the $\mathrm{Al}_{2} \mathrm{O}_{3}$ content was $5.0 \mathrm{~mol} \% \cdot \mathrm{B}_{2} \mathrm{O}_{3}: \mathrm{SiO}_{2}$ ratio was varied from 0 to 1.4. The compositions were abbreviated as SABS-0, SABS-5, SABS-10, SABS-15, and SABS-35 in this study. The numbers represent the mole percent of $\mathrm{B}_{2} \mathrm{O}_{3}$ in each composition. The formation of SABS glasses after quenching was confirmed by XRD study.

\section{B. NMR experiment}

The ${ }^{11} \mathrm{~B},{ }^{29} \mathrm{Si}$, and ${ }^{27} \mathrm{Al}$ MAS NMR spectra of the SABS glass samples were collected with Bruker MAS probes and a Bruker Avance 500 spectrometer equipped with a widebore ultrashield magnet operating at a Larmor frequency of 160.4, 99.5, and $130.3 \mathrm{MHz}$ for ${ }^{11} \mathrm{~B},{ }^{29} \mathrm{Si}$, and ${ }^{27} \mathrm{Al}$, respectively. The applied magnetic field was $11.7 \mathrm{~T} .{ }^{11} \mathrm{~B}$ and ${ }^{27} \mathrm{Al}$ MAS NMR spectra were collected with a $4 \mathrm{~mm}$ probe. Crushed SABS glass samples were spun in $\mathrm{Si}_{3} \mathrm{~N}_{4}$ and $\mathrm{ZrO}_{2}$ rotors at $15 \mathrm{kHz}$. All ${ }^{11} \mathrm{~B}$ and ${ }^{27} \mathrm{Al}$ MAS spectra were collected using nonselective rf pulses with $15^{\circ}$ tip angle and a recycle delay

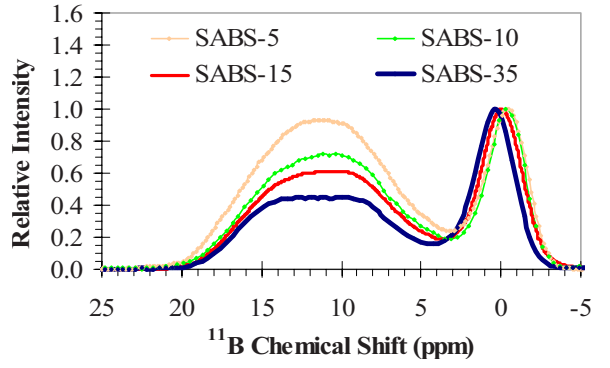

FIG. 1. (Color online) ${ }^{11}$ B MAS NMR spectra of SABS glasses.

of 2 s. Approximately 500 to 1000 free induction decays were averaged to obtain each spectrum. The ${ }^{11} \mathrm{~B}$ and ${ }^{27} \mathrm{Al}$ chemical shifts were externally referenced to $0.1 M \mathrm{Na}_{2} \mathrm{~B}_{4} \mathrm{O}_{7}$ solution at $9.8 \mathrm{ppm}$ and to $1 M \mathrm{AlCl}_{3}$ solution at $0 \mathrm{ppm}$, respectively. For ${ }^{29} \mathrm{Si}$ MAS NMR experiments, the crushed glass samples were spun in a $\mathrm{ZrO}_{2}$ rotor with a $7 \mathrm{~mm}$ Bruker MAS probe. The spectra were collected using rf pulses with $60^{\circ}$ tip angle and a recycle delay of $30 \mathrm{~s}$. Approximately 4000 free induction decays were averaged to obtain each spectrum. ${ }^{29} \mathrm{Si}$ chemical shifts were externally referenced to tetramethyl silane at $0 \mathrm{ppm}$.

\section{Raman spectroscopy}

For Raman spectroscopy analysis of the SABS glass compositions, quenched glass samples were polished to optical finish. Raman spectra of the polished samples were collected in $200-1600 \mathrm{~cm}^{-1}$ wave number range using a Raman spectrometer (JY Horbia LabRam HR 800, Horiba Ltd., Japan) with a charged coupled device detector and Labspec software. The light source was a $514.57 \mathrm{~nm}$ argon laser at 50 $\mathrm{mW}$ power and $400 \mathrm{~s}$ exposure time. The spectra were later corrected to remove background noise and temperature effects. ${ }^{18}$ For data analysis, the Raman spectra were fitted to Gaussian bands without any restriction to deconvolute the superimposed Raman peaks. ${ }^{19,20}$ The curve fitting was done with a GRAMS/AI (7.02) software (Themo Fisher Scientific, Inc. Waltham, MA).

\section{Phase analysis}

For thermal stability study, the SABS glass samples were put on a platinum foil and heated to $850{ }^{\circ} \mathrm{C}$ at the same heating and cooling rate of $5{ }^{\circ} \mathrm{C} \mathrm{min}^{-1}$. The samples were thermally treated at $850{ }^{\circ} \mathrm{C}$ for $50-200 \mathrm{~h}$. XRD studies were carried out in an X'Pert PRO diffractometer (PANalytical B.V., EA Almelo, The Netherlands) to identify the devitrified phases in the thermally treated samples. The scan rate was $0.0020^{\circ} \mathrm{s}^{-1}$ with $\mathrm{Cu} K_{\alpha}$ radiation $(\lambda=1.5406 \AA)$ and a nickel filter.

\section{RESULTS AND DISCUSSIONS}

\section{A. Glass structural unit environment}

The ${ }^{11} \mathrm{~B}$ MAS NMR spectra of the SABS glasses are shown in Fig. 1. SABS-0 composition is not included since it is $\mathrm{B}_{2} \mathrm{O}_{3}$ free. The broad powder pattern on the left (12 ppm peak) and the narrow Gaussian curve on the right $(0 \mathrm{ppm}$ peak) can be readily assigned to $\mathrm{BO}_{3}$ (trigonal boron species) 


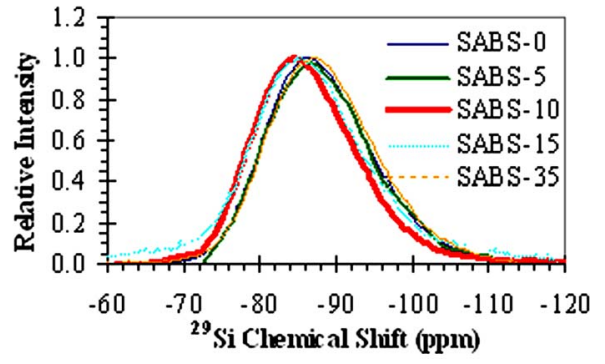

FIG. 2. (Color online) ${ }^{29} \mathrm{Si}$ MAS NMR spectra of SABS glasses.

and $\mathrm{BO}_{4}$ (tetrahedral boron species), respectively. Direct simulation of these spectra is difficult due to the heterogeneous broadening of the $\mathrm{BO}_{3}$ line shape. Instead, these spectra are all normalized to the highest intensity of the $\mathrm{BO}_{4}$ line shape. The relative intensity of the $\mathrm{BO}_{3}$ peak maximum is used as a relative measure of $\mathrm{BO}_{3}: \mathrm{BO}_{4}$ ratio. As seen from Fig. 1, the $\mathrm{BO}_{3}: \mathrm{BO}_{4}$ ratio in the $\mathrm{SABS}$ glasses decreases significantly and systematically with $\mathrm{B}_{2} \mathrm{O}_{3}$ content increase. This means higher $\mathrm{B}_{2} \mathrm{O}_{3}$ content induces $\mathrm{BO}_{4}$ glass structural unit formation. The fundamental cause is that the bonding between $\mathrm{BO}_{3}$ and $\mathrm{SiO}_{4}$ (trigonal and tetrahedral network units) is unfavorable because of their relatively high local charge concentrations. The degree of coordination with $\mathrm{SiO}_{4}$ for $\mathrm{BO}_{3}$ is less than that for $\mathrm{BO}_{4}$, even though $\mathrm{SiO}_{4}$ and $\mathrm{BO}_{4}$ coordination needs to be further examined. ${ }^{21}$

Previous ${ }^{11} \mathrm{~B}$ NMR studies of borosilicate glasses have shown that $\mathrm{BO}_{3}: \mathrm{BO}_{4}$ ratio is independent of $\mathrm{B}_{2} \mathrm{O}_{3}: \mathrm{SiO}_{2}$ ratio at low modifier contents. ${ }^{22}$ However, at high modifier concentrations that are characteristic of the SABS glasses studied here, the $\mathrm{BO}_{3}: \mathrm{BO}_{4}$ ratio is expected to decrease at a rapid rate with $\mathrm{B}_{2} \mathrm{O}_{3}$ content increase. ${ }^{22}$ This structural scenario is consistent with the compositional evolution of the ${ }^{11} \mathrm{~B}$ MAS NMR spectra shown in Fig. 1. As it indicates, the $\mathrm{BO}_{3}: \mathrm{BO}_{4}$ ratio progressively decreases from SABS-5 to SABS-35. It is also interesting to note that the ${ }^{11} \mathrm{~B}$ chemical shift for the $\mathrm{BO}_{3}$ site is located around $11 \mathrm{ppm}$, indicating that these sites contain at least one nonbridging oxygen atom forming a $T^{2}$ boron site (where $T$ stands for "ternary" by analogy to the $Q^{n}$ nomenclature for quaternary silicon). ${ }^{23}$ In addition, the ${ }^{11} \mathrm{~B}$ chemical shift for the $\mathrm{BO}_{4}$ sites shows systematic increase from -0.50 to $0.44 \mathrm{ppm}$ with increasing $\mathrm{B}_{2} \mathrm{O}_{3}$ content from SABS-5 to SABS-35. This result means that increasing ${ }^{11} \mathrm{~B}$ chemical shift for the $\mathrm{BO}_{4}$ sites causes less sharing of oxygen between $\mathrm{BO}_{4}$ and $\mathrm{SiO}_{4}$ tetrahedra from SABS-5 to SABS-35. ${ }^{24}$ The bonding between $\mathrm{BO}_{4}$ and $\mathrm{SiO}_{4}$ is better than that between $\mathrm{BO}_{3}$ and $\mathrm{SiO}_{4}$ but keeps decreasing from SABS-5 to SABS-35.

The ${ }^{29} \mathrm{Si}$ MAS spectra of the SABS glasses are shown in Fig. 2. These spectra show a slightly asymmetric peak that centers from -85 to $-87 \mathrm{ppm}$. The absence of $\mathrm{B}_{2} \mathrm{O}_{3}$ in the SABS-0 glass and the small amount of $\mathrm{Al}_{2} \mathrm{O}_{3}$ (in comparison to $\mathrm{SiO}_{2}$ ) make the ${ }^{29} \mathrm{Si}$ peak assignment straightforward. The main structural unit is $Q^{3}$ (chemical shift of $\left.\sim-87 \mathrm{ppm}\right){ }^{25}$ The shoulder near $-100 \mathrm{ppm}$ indicates the presence of a small amount of $Q^{4}$ species with one or two aluminum as next-nearest neighbors. The ${ }^{29} \mathrm{Si}$ MAS NMR spectra of SABS-5 to SABS-10 are very similar to that of SABS-0, in

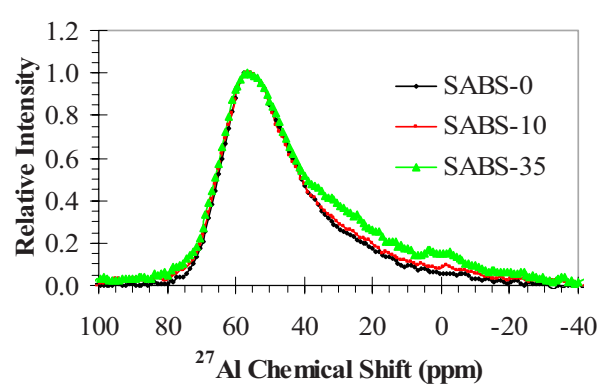

FIG. 3. (Color online) $\mathrm{Al}{ }^{27}$ MAS NMR spectra of SABS-0, SABS-10, and SABS-35 glasses.

spite of the increase in the $\mathrm{B}_{2} \mathrm{O}_{3}$ content. This observation implies that $\mathrm{SiO}_{4}$ tetrahedrals in these glasses share oxygen with $\mathrm{BO}_{3}$ units to a certain extent. However, as mentioned above, the systematic change in the ${ }^{11} \mathrm{~B}$ chemical shift of $\mathrm{BO}_{4}$ units in these glasses indicates preferred linking of $\mathrm{BO}_{4}$ and $\mathrm{SiO}_{4}$ tetrahedra, which begins to influence the ${ }^{29} \mathrm{Si}$ chemical shift in SABS-15 and SABS-35 glasses. In SABS35 , characterized by the highest $\mathrm{B}_{2} \mathrm{O}_{3}$ content and the lowest $\mathrm{BO}_{3}: \mathrm{BO}_{4}$ ratio, the entire ${ }^{29} \mathrm{Si}$ MAS NMR spectrum shifts to higher chemical shift values indicating either the formation of $Q^{2}$ species or $Q^{3}$ species linked with multiple $B^{\mathrm{IV}}$ nextnearest neighbors. SABS-15 glass reveals a chemical shift in between those of SABS-10 and SABS-35. This means at low $\mathrm{B}_{2} \mathrm{O}_{3}$ content $\mathrm{SiO}_{4}$ structural units may bond with $\mathrm{BO}_{3}$ structural units. As $\mathrm{B}_{2} \mathrm{O}_{3}$ content increases, $\mathrm{BO}_{4}$ content increases; $\mathrm{SiO}_{4}$ structural units are more likely to bond with $\mathrm{BO}_{4}$ structural units.

For clarity, only the ${ }^{27}$ Al MAS NMR spectra of SABS-0, SABS-10, and SABS-35 glasses are shown in Fig. 3. These spectra are nearly identical and dominated by a strong, asymmetric peak positioned at $56 \mathrm{ppm}$ that corresponds to tetrahedrally coordinated aluminum with a distribution of quadrupolar coupling coefficients, typical of oxide glasses. This means $\mathrm{Al}_{2} \mathrm{O}_{3}$ mainly acts as a glass former in the SABS glasses. As reported before, the addition of $\mathrm{Al}_{2} \mathrm{O}_{3}$ can reduce the degree of phase separation in the SABS glasses; possibly by the formation of B-O-Al-O-Si linkages. These two observations are consistent. The ${ }^{27} \mathrm{Al}$ MAS NMR spectrum of SABS-35 displays clear but small shoulders near 28 and 0 ppm that correspond to small concentrations (a few \%) of five- and six-coordinated aluminum. ${ }^{11}$ This result is not surprising, as the structure of this glass with its low $\mathrm{SiO}_{2}$ content would have a strong presence of boroaluminate network. Such networks are typically characterized by the presence of five- and six-coordinated aluminum atoms forming Al-O-B linkages. ${ }^{11}$ This observation indicates that whether aluminum acts as a glass former or as a glass modifier depends on the $\mathrm{B}_{2} \mathrm{O}_{3}$ content in borosilicate glass. Even though $\mathrm{Al}_{2} \mathrm{O}_{3}$ mostly acts as a glass former, $\mathrm{B}_{2} \mathrm{O}_{3}$ content increase could change it to a glass modifier. The quantity of $\mathrm{Al}_{2} \mathrm{O}_{3}$ as a glass former in the SABS glasses requires ${ }^{27} \mathrm{Al}$ triple-quantum MAS NMR studies.

\section{B. Glass structural unit local ordering}

To understand the atomic level bonding structure of the SABS glasses, deconvoluted Raman spectra for the SABS 


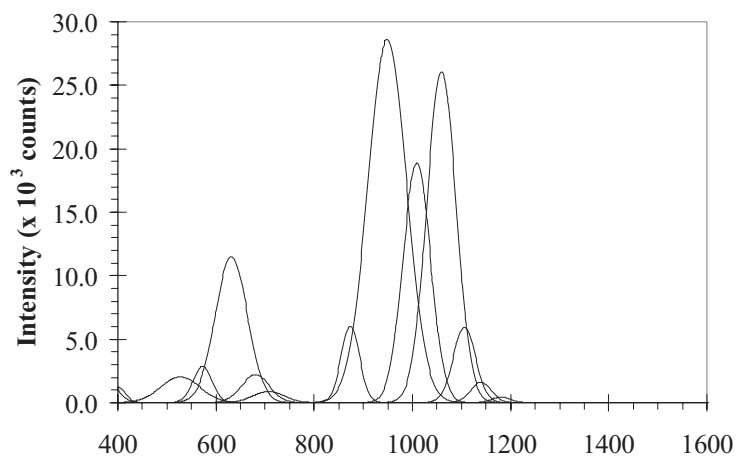

(a)

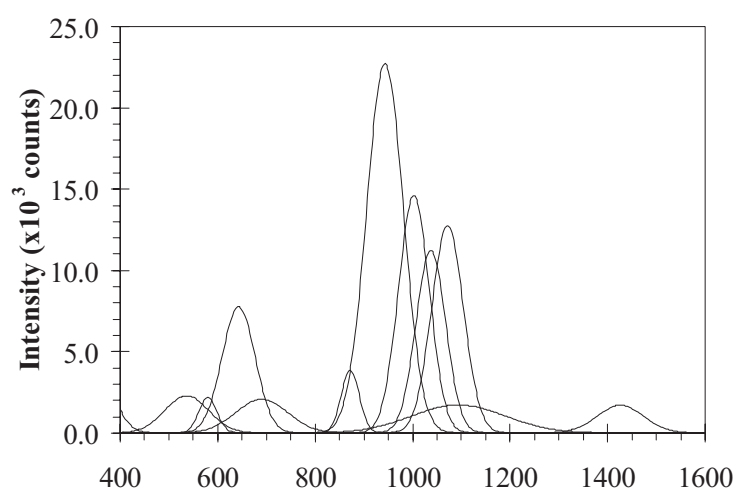

(b)

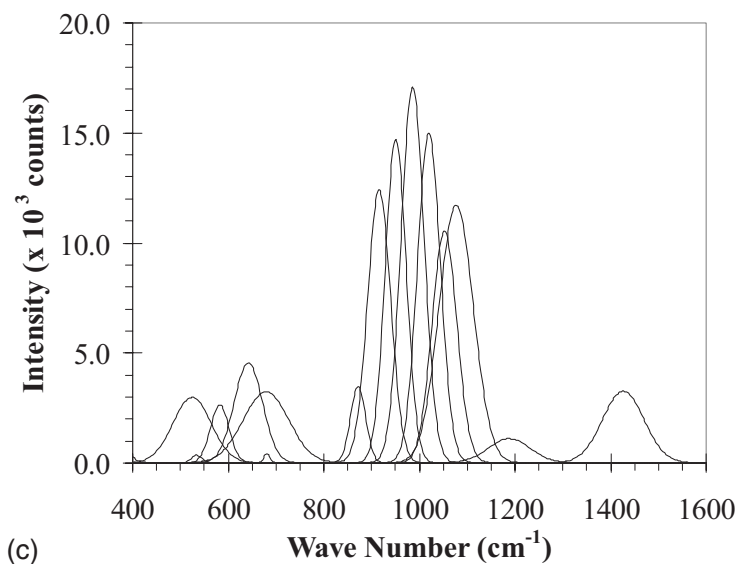



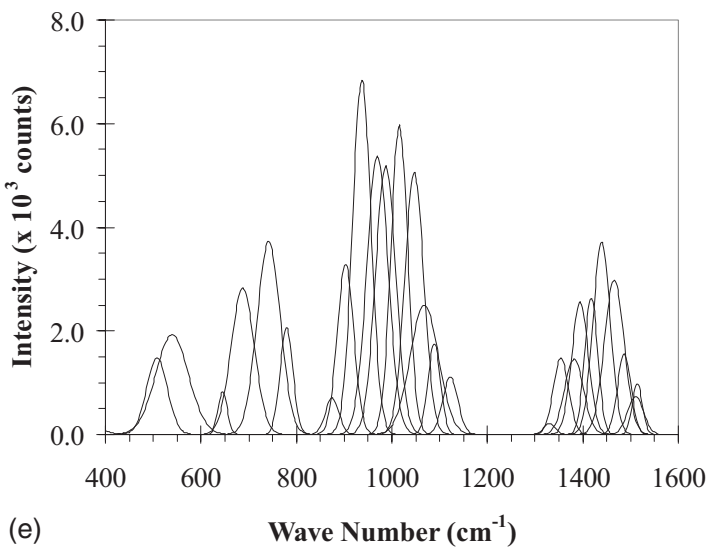

(e)

FIG. 4. Deconvoluted Raman peaks for (a) SABS-0, (b) SABS-5, (c) SABS-10, (d) SABS-15, and (e) SABS-35.

glasses are shown in Fig. 4. Before analyzing the structural units and coordination of the SABS glasses, it is beneficial to examine silicate glass and borate glass structures first. In silicate glass, there are four major Raman peaks representing the nature and contribution of the different silicate structural units. The $1050-1100 \mathrm{~cm}^{-1}$ wave number region describes the stretching motion of the $Q^{3}$ units. The $950-1000 \mathrm{~cm}^{-1}$ wave number peak describes the stretching motion of the $Q^{2}$ units. The $900 \mathrm{~cm}^{-1}$ wave number peak reflects the pyrosilicate composition with the $Q^{1}$ units. The $850 \mathrm{~cm}^{-1}$ wave number peak represents the $Q^{0}$ units. ${ }^{13}$ The $400-700 \mathrm{~cm}^{-1}$ wave number peak represents the delocalized vibration of $\mathrm{Si}-\mathrm{O}-\mathrm{Si}$ from mixed stretching and bending modes. ${ }^{17}$ In borate glass, the $1200-1600 \mathrm{~cm}^{-1}$ peak describes the $\mathrm{B}-\mathrm{O}^{-}$ $\left(\mathrm{O}^{-}\right.$denotes the nonbridging oxygen) stretching mode within the chain and ring metaborates. ${ }^{26}$ The low frequency region of the $1400 \mathrm{~cm}^{-1}$ band can be attributed to $\mathrm{BO}_{3}$ trigonals linked to $\mathrm{BO}_{4}$ tetrahedrals, exhibiting a lower vibration frequency as a result of $\pi^{-}$electronic interaction. ${ }^{27}$ Based on the above understanding, peaks in different wave number ranges of the SABS glass spectra can be identified.

For the SABS-0 glass, no peaks are detected in the $1300-1600 \mathrm{~cm}^{-1}$ range, corresponding to the Raman peaks from $\mathrm{B}_{2} \mathrm{O}_{3}$. This is easy to understand because the SABS-0 glass is $\mathrm{B}_{2} \mathrm{O}_{3}$-free. For the SABS-5 and SABS-10 glasses, the $1426 \mathrm{~cm}^{-1}$ peak can be assigned to localized stretching vibration of $\mathrm{B}-\mathrm{O}^{-}$bonds from metaborate units. ${ }^{16}$ For the SABS-15 glass, the presence of 1357 and $1387 \mathrm{~cm}^{-1}$ peaks indicate the $\mathrm{B}-\mathrm{O}^{-}$vibrations in a large borate network. ${ }^{17}$ The peaks at $1424,1452,1460$, and $1501 \mathrm{~cm}^{-1}$ can be as- 
signed to metaborate units and localized stretching vibration modes of $\mathrm{B}-\mathrm{O}^{-}$bonds, as for the $1426 \mathrm{~cm}^{-1}$ wave number peak in the SABS-5 and SABS-10 glasses. ${ }^{16}$ In addition, the $1479 \mathrm{~cm}^{-1}$ peak is attributed to the stretching mode of disordered $\mathrm{BO}_{3}$ triangles. ${ }^{10}$ The 1402 and $1438 \mathrm{~cm}^{-1}$ peaks cannot be identified. In the SABS-35 glass, the $1487 \mathrm{~cm}^{-1}$ peak can be attributed to the stretching mode of disordered $\mathrm{BO}_{3}$ triangles. ${ }^{10}$ With the increasing intertetrahedral angle, one peak for the borate glass splits into three peaks, one at lower wave number, another at higher wave number, and one remaining at the same wave number. ${ }^{28}$ For the SABS-35 glass, the peaks at 1354,1382 , and $1394 \mathrm{~cm}^{-1}$ can be assigned to the splitted $1380 \mathrm{~cm}^{-1}$ peak identified for the $\mathrm{B}-\mathrm{O}^{-}$vibration. ${ }^{17}$ The peaks at 1466,1510 , and $1514 \mathrm{~cm}^{-1}$ can be assigned to localized stretching vibration of $\mathrm{B}-\mathrm{O}^{-}$ bonds. ${ }^{16}$ The 1330,1417 , and $1443 \mathrm{~cm}^{-1}$ peaks cannot be identified. In general, Raman peak splitting in this high wave number region increases with $\mathrm{B}_{2} \mathrm{O}_{3}$ content increase. From this analysis, it can be concluded that $\mathrm{B}_{2} \mathrm{O}_{3}$ progressively affects the glass network structure by $\mathrm{B}-\mathrm{O}^{-}$vibration and stretching modes; high amount of $\mathrm{B}_{2} \mathrm{O}_{3}$ also causes more borate structural unit ordering. ${ }^{17}$

In the $800-1200 \mathrm{~cm}^{-1}$ region, for the SABS-0 glass, the weak 1143 and $1180 \mathrm{~cm}^{-1}$ peaks correspond to the splitted $1060-1200 \mathrm{~cm}^{-1}$ peak in vitreous silica. ${ }^{29}$ These peaks describe the $Q^{4}$ units. The 1060 and $1105 \mathrm{~cm}^{-1}$ peaks are from the $Q^{3}$ units. The 949 and $1010 \mathrm{~cm}^{-1}$ peaks are from the $Q^{2}$ units. The $872 \mathrm{~cm}^{-1}$ peak is from the $Q^{0}$ units. For the SABS-5 glass, no $Q^{4}$ structural units are detected. The 1036 , 1072 , and $1094 \mathrm{~cm}^{-1}$ peaks are from the $Q^{3}$ units. The 943 and $1003 \mathrm{~cm}^{-1}$ peaks are from the $Q^{2}$ units. The $872 \mathrm{~cm}^{-1}$ peak is from the $Q^{0}$ units. In the SABS-10 glass, the weak peak at $1188 \mathrm{~cm}^{-1}$ is from the diborate groups. The peaks at 1053 and $1077 \mathrm{~cm}^{-1}$ are from the $Q^{3}$ units. The peaks at 951,986 , and $1020 \mathrm{~cm}^{-1}$ are from the $Q^{2}$ units. The peak at $916 \mathrm{~cm}^{-1}$ is from the $Q^{1}$ units. The $872 \mathrm{~cm}^{-1}$ peak is from the $Q^{0}$ units. This means the glass structure continues to become less connected, and borate structural units start to play a role in the glass network. For the SABS-15 glass, the $1056 \mathrm{~cm}^{-1}$ peak is from the $Q^{3}$ units. The 952 to $1028 \mathrm{~cm}^{-1}$ peaks are from the $Q^{2}$ units. The $929 \mathrm{~cm}^{-1}$ peak can be attributed to $\mathrm{Si}(\mathrm{OAl})_{3}$ units with one bridging oxygen atom. ${ }^{30}$ The $904 \mathrm{~cm}^{-1}$ peak is also from the $Q^{1}$ units. For the SABS-35 glass, the $1122 \mathrm{~cm}^{-1}$ peak is attributed to the diborate groups. The 1068 and $1089 \mathrm{~cm}^{-1}$ peaks are attributed to the $Q^{3}$ units. The $970-1047 \mathrm{~cm}^{-1}$ peaks are attributed to the $Q^{2}$ units. The $937 \mathrm{~cm}^{-1}$ peak is from orthoborate units. The $903 \mathrm{~cm}^{-1}$ peak corresponds to the $Q^{1}$ units. The $875 \mathrm{~cm}^{-1}$ peak is from the $Q^{0}$ units. Some $\mathrm{BO}_{4}$ structural units appear to be isolated, a continuing trend of more $\mathrm{B}_{2} \mathrm{O}_{3}$ involvement in the SABS glass network. Overall, this $800-1200 \mathrm{~cm}^{-1}$ range peak splitting evolution shows that as $\mathrm{B}_{2} \mathrm{O}_{3}$ content increases, there are increased weakening of the SABS glass network and local ordering of the silicate and borate structural units.

In the $400-800 \mathrm{~cm}^{-1}$ region, for the SABS-0 glass, the 619 and $641 \mathrm{~cm}^{-1}$ peaks are from the $Q^{2}$ units. The $605 \mathrm{~cm}^{-1}$ peak is from the $Q^{3}$ units. For the SABS-5 glass, the $690 \mathrm{~cm}^{-1}$ peak is from the $Q^{1}$ units. The $643 \mathrm{~cm}^{-1}$ peak is from the $Q^{2}$ units. The 537 and $580 \mathrm{~cm}^{-1}$ peaks are from the $\mathrm{BO}_{4}^{-}$units in anionic rings. Borate structural units appear when the glass composition changes from SABS-0 to SABS-5. For the SABS-10 glass, the 679 and $680 \mathrm{~cm}^{-1}$ peaks are from the $Q^{1}$ units. Some metaborate units may also contribute to these peaks. The $642 \mathrm{~cm}^{-1}$ peak is from the $Q^{2}$ units. The peaks at 524, 534, and $582 \mathrm{~cm}^{-1}$ are from $\mathrm{BO}_{4}^{-}$ anionic rings. For the SABS-15 glass, the $471 \mathrm{~cm}^{-1}$ peak is from the $Q^{3}$ units but may also have contribution from the bending mode of $\mathrm{B}-\mathrm{O}-\mathrm{B}, \mathrm{B}-\mathrm{O}-\mathrm{Si}$, and $\mathrm{Si}-\mathrm{O}-\mathrm{Si}$ linkages. ${ }^{22}$ The $446 \mathrm{~cm}^{-1}$ peak is from the $Q^{4}$ units. The 517 and $583 \mathrm{~cm}^{-1}$ peaks are from $\mathrm{BO}_{4}^{-}$units. The $741-744 \mathrm{~cm}^{-1}$ peaks are attributed to $\mathrm{BO}_{4}^{-}$tetrahedral units with nonbridging oxygen atoms. The 677 and $704 \mathrm{~cm}^{-1}$ peaks are attributed to the $Q^{1}$ units along with some metaborate units. The $644 \mathrm{~cm}^{-1}$ peak is attributed to the $Q^{2}$ units. In the SABS-35 glass, simultaneous appearance of 508, 645, 779, and $937 \mathrm{~cm}^{-1}$ peaks confirms the presence of pentaborate structural units. The $742 \mathrm{~cm}^{-1}$ peak is attributed to $\mathrm{BO}_{4}^{-}$tetrahedrals. The $467 \mathrm{~cm}^{-1}$ peak is from the $\mathrm{B}-\mathrm{O}-\mathrm{Si}$ linkages. The $688 \mathrm{~cm}^{-1}$ peak is attributed to $\mathrm{B}-\mathrm{O}-\mathrm{Si}$ linkages from the $Q^{1}$ units. The $539 \mathrm{~cm}^{-1}$ peak is attributed to the $\mathrm{BO}_{4}^{-}$units. As it shows, from SABS-0 to SABS-35, $T^{n}$ peak splitting increases. This means the SABS glass structure is increasingly affected by $\mathrm{B}_{2} \mathrm{O}_{3}$, structural units become more localized, and mixed bonding also increases.

\section{Connectivity}

Thermal properties of a glass depend on the presence of atomic level structural units, their relative arrangement, and the amounts of bridging and nonbridging oxygen atoms. ${ }^{31}$ This is because these structural parameters determine the glass network connectivity. If a glass has high connectivity, then it is likely to be stable and resistant to devitrification. If a glass has low connectivity, then it is likely to devitrify. Increasing nonbridging oxygen content decreases glass connectivity. In the SABS glass system, $\mathrm{B}_{2} \mathrm{O}_{3}$ becomes more dominant in the glass structure as its content increases. Along with the increase in the relative percent of $\mathrm{BO}_{4}$ structural units, the absolute content of $\mathrm{BO}_{3}$ structural units still increases. This leads to more chain and ring metaborate and even orthoborate (for SABS-35) contents and increasingly broken $\mathrm{SiO}_{4}$ tetrahedral network. As a result, connectivity decreases.

Quantitatively, glass network connectivity $\psi$ can be defined as follows based on prior knowledge of degree of network formation: ${ }^{32}$

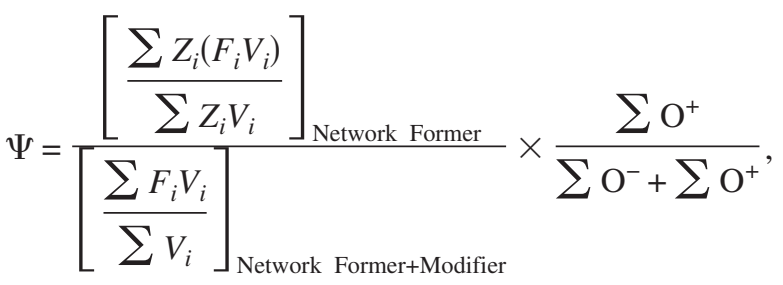

where $F_{i}$ is the field strength of oxide $i$ in a glass system, $V_{i}$ is the amount of oxide $i$ in vol $\%$, and $Z_{i}$ is the atomic number of oxide $i$. The first term in Eq. (1) considers the bonding effect of cations that are present in a glass network. The 
TABLE I. Calculated glass network connectivity for SABS glasses.

\begin{tabular}{lccc}
\hline \hline Composition & $\left.\left[\Sigma Z_{i}\left(F_{i} V_{i}\right) / \Sigma Z_{i} V_{i}\right]_{\text {Network Former }} / \Sigma F_{i} V_{i} / \Sigma V_{i}\right]_{\text {Network Former+Modifier }}$ & $\Sigma \mathrm{O}^{+} / \Sigma \mathrm{O}^{-}+\Sigma \mathrm{O}^{+}$ & Glass network connectivity $\psi(\%)$ \\
\hline SABS-0 & 1.40 & 0.53 & 74 \\
SABS-5 & 1.38 & 0.52 & 72 \\
SABS-10 & 1.37 & 0.48 & 66 \\
SABS-15 & 1.36 & 0.49 & 66 \\
SABS-35 & 1.31 & 0.37 & 48 \\
\hline \hline
\end{tabular}

second term represents the ratio of bridging oxygen atoms $\left(\mathrm{O}^{+}\right)$versus the total oxygen atoms $\left(\mathrm{O}^{-}\right.$and $\left.\mathrm{O}^{+}\right)$in a glass network. $\psi$ thus represents two aspects in a glass network: bonding effect of glass network cations and the ratio of bridging oxygen atoms versus the total oxygen atoms.

Based on the SABS glass compositions, the NMR spectra and the Raman spectra glass network connectivity for the SABS glasses has been calculated using Eq. (1) and the results are given in Table I. The field strength of $\mathrm{SiO}_{2}, \mathrm{Al}_{2} \mathrm{O}_{3}$, $\mathrm{La}_{2} \mathrm{O}_{3}$, and $\mathrm{SrO}$ are 1.56, 0.97, 0.43, and 0.27, respectively, based on literature values and the cation function in the SABS glasses. ${ }^{33}$ The field strength of $\mathrm{B}_{2} \mathrm{O}_{3}$ varies between 1.53 to 1.50 based on literature values and the $\mathrm{BO}_{3}: \mathrm{BO}_{4}$ ratios from SABS-0 to SABS- $35 .{ }^{33}$ As it shows, the bonding ability of glass network cations, the relative percent of bridging oxygen atoms, and the SABS glass network connectivity all decrease with $\mathrm{B}_{2} \mathrm{O}_{3}$ content increase. This result is very consistent with the NMR and Raman spectra, as well as the SABS glass thermal stability to be discussed. Glass connectivity serves as an important parameter in evaluating the thermal stability of a glass system.

While the connectivity calculation sheds new light on the glass network structure, it should be cautioned that the connectivity results in Table I involve two approximations. First, the amount of network forming cations contributed by $\mathrm{Al}^{3+}$ ions is unknown. $\mathrm{Al}_{2} \mathrm{O}_{3}$ participates in the glass network as a glass former but the relative amount decreases with $\mathrm{B}_{2} \mathrm{O}_{3}$ content increase. For the calculation in Table I, $\mathrm{Al}_{2} \mathrm{O}_{3}$ is assumed to always act as a glass former throughout the SABS glass composition range. Second, there are two Raman peaks for SABS-15 (1402 and $1438 \mathrm{~cm}^{-1}$ ) and three Raman peaks for SABS-35 (1330, 1417, and $\left.1443 \mathrm{~cm}^{-1}\right)$ that cannot be identified. In this calculation, they are assumed to come from borate structural units coordinated with glass modifiers. Detailed network structure analysis will be beneficial for addressing these two approximations and potentially provide more consistent trend.

Because of the configurational entropy difference between $\mathrm{SiO}_{4}$ and $\mathrm{BO}_{3}$ structural units, $\mathrm{SiO}_{4}$ structural units preferentially link with $\mathrm{BO}_{4}$ structural units, except for the linking among themselves. To understand the degree of bonding between $\mathrm{SiO}_{4}$ and $\mathrm{BO}_{4}$ units, two other related parameters can be calculated. One is the probability of silicon coordinated to $\mathrm{BO}_{4}$ and the other is mean number of silicon coordinated to $\mathrm{BO}_{4}$. $\mathrm{SiO}_{4}$ and $\mathrm{BO}_{4}$ structural unit coordination has been discussed previously but is desired to be further quantified. For a given glass, the mean number of silicon coordinated to $\mathrm{BO}_{4}$ species is approximately constant and can be averaged over compositions of SABS-0 to SABS-35.
Taking $X_{\mathrm{Si}}$ as the molar ratio of silicon to total network formers (silicon and boron) and assuming no $\mathrm{BO}_{4}$ units are linked with each other, the mean number of silicon coordinated to $\mathrm{BO}_{4}$ can be expressed as ${ }^{34}$

$$
\langle l\rangle=\frac{16 X_{\mathrm{Si}}}{0.62+4.38 X_{\mathrm{Si}}-X_{\mathrm{Si}}^{2}} .
$$

The probability of silicon coordinated to $\mathrm{BO}_{4}$ becomes

$$
\begin{aligned}
P(l)= & \frac{4 !}{l !(4-l) !}\left(\frac{4 X_{S i}}{0.62+4.38 X_{S i}-X_{\mathrm{Si}}^{2}}\right)^{l} \\
& \times\left(\frac{0.62+0.38 X_{S i}-X_{\mathrm{Si}}^{2}}{0.62+4.38 X_{S i}-X_{\mathrm{Si}}^{2}}\right)^{4-l} .
\end{aligned}
$$

Based on Eqs. (2) and (3), $\langle l\rangle$ and $P(l)$ can be calculated for the SABS glasses as shown in Fig. 5. $\langle l\rangle$ and $P(l)$ drastically decrease with $\mathrm{B}_{2} \mathrm{O}_{3}$ content increase. For SABS-5, the average mean number of silicon coordinated to $\mathrm{BO}_{4}$ is 3.75 ; the probability $P(l)$ of finding silicon coordinated to $\mathrm{BO}_{4}$ is 0.77 . For SABS-35, the average mean number of silicon coordinated to $\mathrm{BO}_{4}$ is 2.47 ; the probability $P(l)$ of finding silicon coordinated to $\mathrm{BO}_{4}$ is 0.33 . For SABS-10 and SABS-15, the values of $\langle l\rangle$ and $P(l)$ are in between the above ranges. This means as $\mathrm{B}_{2} \mathrm{O}_{3}$ content increases, there are not only fewer silicon atoms coordinated to $\mathrm{BO}_{4}$ but the possibility of finding such coordination also drastically decreases. To put it differently, $\mathrm{SiO}_{4}$ and $\mathrm{BO}_{4}$ structural units are less and less likely to bond with each other with $\mathrm{B}_{2} \mathrm{O}_{3}$ content increase, even by assuming no $\mathrm{BO}_{4}$ units are directly linked with themselves, an extreme assumption supported by the NMR results. This indicates that the glass network connectivity results in Table I should be considered jointly with the $Q^{n}$ and $T^{n}$ structural units distribution and bonding when evaluating a glass system, such as thermal stability.

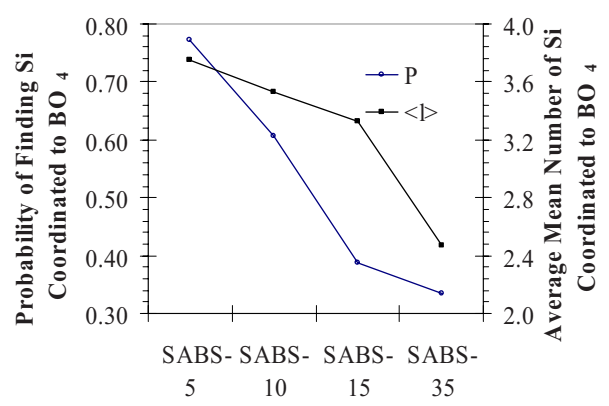

FIG. 5. (Color online) Probability of silicon coordinated to $\mathrm{BO}_{4}$ and average mean number of silicon coordinated to $\mathrm{BO}_{4}$ as a function of SABS glass composition. 


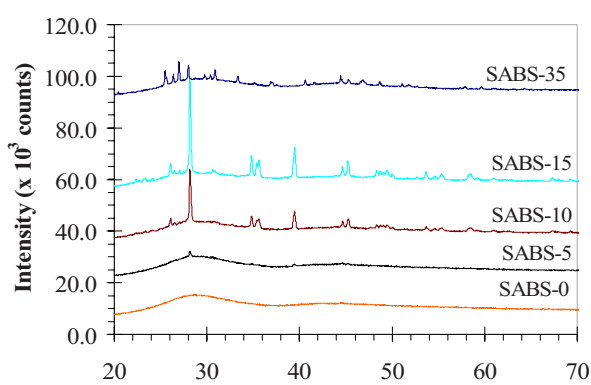

FIG. 6. (Color online) XRD patterns of SABS glasses thermally treated at $850{ }^{\circ} \mathrm{C}$ for $50 \mathrm{~h}$.

\section{Thermal stability}

Glass network connectivity and homogeneity directly influence the devitrification resistance of a glass system. The decrease in glass network connectivity and the increase in glass structural unit inhomogeneity enhance the probability of glass devitrification. If structural unit local ordering occurs in a glass, even if only in small localized regions, the glass will be prone to devitrification, likely caused by heterogeneous nucleation. ${ }^{7}$ For the studied SABS systems, the glass thermal stability can be evaluated by comparing the thermal treatment time to devitrification and the specific types of devitrified phases. Gibbs free energy change during the devitrification process may be the most precise approach to explain the devitrification tendency and the most likely devitrifying phase. However, thermodynamic data for the SABS glass systems at high temperatures are not available, especially for the species involving $\mathrm{SrO}$ and $\mathrm{La}_{2} \mathrm{O}_{3}$ modifiers. With the NMR and Raman spectra providing complementary data about $\mathrm{BO}_{3}: \mathrm{BO}_{4}$ ratios, environment of different structural units, as well as structural unit types, ordering, and distribution, XRD serves as an effective means to identifying the devitrified phases.

For the SABS glasses thermally treated at $850{ }^{\circ} \mathrm{C}$ for 50 $\mathrm{h}$, the XRD patterns are given in Fig. 6. As can be seen, the SABS-0 glass shows no sign of devitrification after $50 \mathrm{~h}$ thermal treatment, suggesting that the SABS-0 glass is stable under such thermal treatment condition. The SABS-5 glass devitrifies after $50 \mathrm{~h}$ of thermal treatment. Small devitrification peaks are observed but the intensity and number of the peaks are insufficient to determine the devitrified phases. This result means SABS-5 is less stable than SABS-0 but not so unstable as to cause extensive devitrification. However, as $\mathrm{B}_{2} \mathrm{O}_{3}$ content continues to increase, SABS-10, SABS-15, and SABS-35 glass samples show more extensive devitrification after thermal treatment at $850{ }^{\circ} \mathrm{C}$ for $50 \mathrm{~h}$. Monoclinic lanthanum silicate $\left(\mathrm{La}_{2} \mathrm{Si}_{2} \mathrm{O}_{7}\right)$ is the only phase in the SABS-10 glass. This means $\mathrm{SiO}_{4}$ structural units interact with glass modifier $\mathrm{La}_{2} \mathrm{O}_{3}$. However, in the SABS-15 glass, three phases are identified. They are monoclinic lanthanum silicate $\left(\mathrm{La}_{2} \mathrm{Si}_{2} \mathrm{O}_{7}\right)$, rhombohedral aluminum borate $\left(\mathrm{AlBO}_{3}\right)$, and orthorhombic strontium boron aluminum oxide $\left(\mathrm{Sr}_{2} \mathrm{~B}_{2} \mathrm{Al}_{2} \mathrm{O}_{8}\right)$. In the SABS-35 glass, two phases, orthorhombic strontium borate $\left(\mathrm{SrB}_{2} \mathrm{O}_{4}\right)$ and orthorhombic lanthanum borate $\left(\mathrm{LaBO}_{3}\right)$, are identified. $\mathrm{LaBO}_{3}$ is the main phase. New phases in the SABS-15 and SABS-35 glasses can be seen in the new peak appearance and peak shifting in the

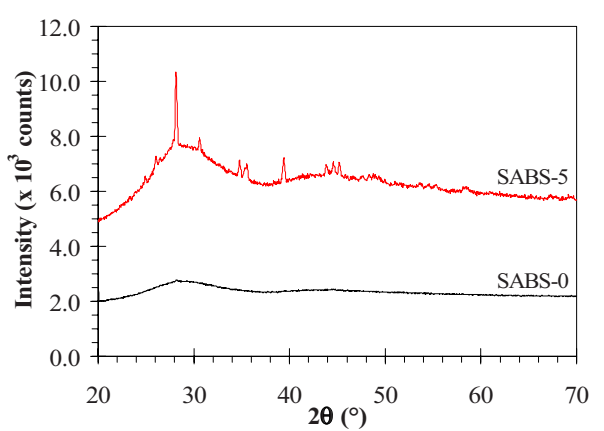

FIG. 7. (Color online) XRD patterns of SABS-0 and SABS-5 glasses thermally treated at $850{ }^{\circ} \mathrm{C}$ for $100 \mathrm{~h}$.

XRD patterns from SABS-10 to SABS-15, then to SABS-35 (Fig. 6). Boron-containing devitrification phase appearance means that $\mathrm{BO}_{3} / \mathrm{BO}_{4}$ structural units become unstable and start to interact with glass modifiers $\left(\mathrm{SrO}\right.$ and $\left.\mathrm{La}_{2} \mathrm{O}_{3}\right)$ and intermediate $\left(\mathrm{Al}_{2} \mathrm{O}_{3}\right)$ along with $\mathrm{SiO}_{4}$ structural units. The bonding energy of $\mathrm{Si}-\mathrm{O}-\mathrm{B}^{\mathrm{III}}$ bond is $119 \mathrm{kcal} / \mathrm{mol}$, which is higher than that of $\mathrm{Si}-\mathrm{O}-\mathrm{B}^{\mathrm{IV}}$ bond at $89 \mathrm{kcal} / \mathrm{mol}^{35}$ Therefore, SABS glass thermal stability decreases as the amount of four-coordinated $\mathrm{BO}_{4}$ units increases for higher $\mathrm{B}_{2} \mathrm{O}_{3}$ content. In addition, the SABS glasses contain $\mathrm{La}^{3+}$ and $\mathrm{Sr}^{2+}$ cations, which have a higher tendency to bond with the glass forming cations through nonbridging oxygen atoms than monovalent cations. ${ }^{10,36} \mathrm{So}, \mathrm{La}_{2} \mathrm{Si}_{2} \mathrm{O}_{7}$ is the major devitrified phases in all boron-containing SABS glasses except for SABS-35.

For the SABS-0 and SABS-5 glasses, which are more stable, Fig. 7 shows the XRD patterns after $100 \mathrm{~h}$ of thermal treatment at $850{ }^{\circ} \mathrm{C}$. Still, the SABS-0 glass shows no signs of devitrification and continues to demonstrate itself as a very stable high temperature glass. For the SABS-5 glass, monoclinic $\mathrm{La}_{2} \mathrm{Si}_{2} \mathrm{O}_{7}$ is the main phase along with small amounts of $\alpha-\mathrm{SrSiO}_{3}$ and $\mathrm{Sr}_{2} \mathrm{SiO}_{4}$ phases. This means when the glass network connectivity decreases, the $T^{n}$ and $Q^{n}$ structural units are less likely to bond with each other. $\mathrm{SiO}_{4}$ structural units become more likely to interact with glass modifiers, such as $\mathrm{SrO}$ and $\mathrm{La}_{2} \mathrm{O}_{3}$, and form new species. This interaction leads to devitrification and Sr-containing crystalline phase formation. Nonetheless, the $\mathrm{B}_{2} \mathrm{O}_{3}$ content for the SABS-5 glass is low enough that the system is more stable than the other higher $\mathrm{B}_{2} \mathrm{O}_{3}$ content $\mathrm{SABS}$ glasses.

Figure 8 shows the XRD pattern of the SABS-0 glass after $200 \mathrm{~h}$ of thermal treatment at $850{ }^{\circ} \mathrm{C}$. Very desirably, the SABS-0 glass is still amorphous with no devitrified

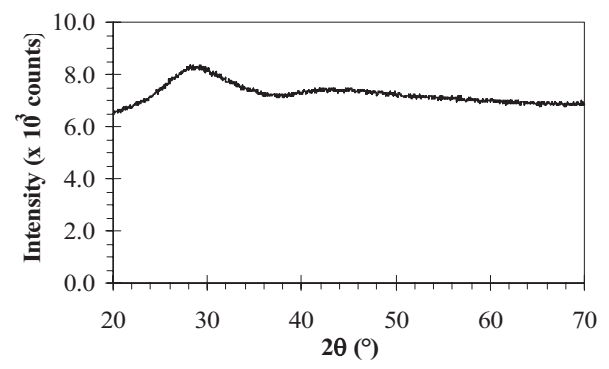

FIG. 8. XRD pattern of SABS-0 glass thermally treated at $850{ }^{\circ} \mathrm{C}$ for 200 h. 
phase, demonstrated by the broad XRD pattern. This result is consistent with the glass network connectivity calculation. In Table I, the SABS-0 glass has the highest bonding ability, relative bridging oxygen content, and overall network connectivity. Therefore, the SABS-0 glass is the most thermally stable among all the studied glass compositions. This confirms that a glass network requires high connectivity for improved thermal stability. Absence of $\mathrm{B}_{2} \mathrm{O}_{3}$ content is conducive for bridging oxygen formation and devitrification resistance improvement.

With increasing $\mathrm{B}_{2} \mathrm{O}_{3}$ content, different devitrified phases evolve. This indicates that the devitrification process is accompanied by complex interaction among different glass structural units and glass modifiers. $\mathrm{B}_{2} \mathrm{O}_{3}$ decreases SABS glass network connectivity and glass structural unit coordination. The amount of bridging oxygen atoms decreases with the decrease in glass structure connectivity. The nonbridging oxygen atoms have a tendency to coordinate with the glass modifiers and form new species. The devitrified phase identification from the XRD study is consistent with the Raman data. In the SABS glasses, $\mathrm{La}^{3+}$ and $\mathrm{Sr}^{2+}$ ions act as modifiers. The intense peaks around $1028 \mathrm{~cm}^{-1}$ wave number in the SABS-10 and SABS-15 glasses suggest that the nonbridging oxygen atoms from the $\mathrm{SiO}_{4}$ structural units may coordinate with $\mathrm{La}^{3+} \cdot{ }^{37}$ Also, these $\mathrm{La}-\mathrm{O}-\mathrm{Si}$ containing linkages may be isolated and act as nucleation sites. Correspondingly, $\mathrm{La}_{2} \mathrm{Si}_{2} \mathrm{O}_{7}$ phase is shown in the thermally treated SABS-10 and SABS-15 glasses from the XRD study. No Raman peak around $1028 \mathrm{~cm}^{-1}$ wave number is observed for SABS-5 even though $\mathrm{La}_{2} \mathrm{Si}_{2} \mathrm{O}_{7}$ phase is present. This could be because the La-O-Si linkage content is too low to be detectable for SABS-5. For the SABS-35 glass, similar argument can be applied. Some nonbridging oxygen atoms are coordinated with $\mathrm{Sr}^{2+}$ ions and thus strontium-containing phases evolve. Several peaks above $1300 \mathrm{~cm}^{-1}$ wave number are similar to the crystalline phase $\mathrm{La}\left(\mathrm{B}_{3} \mathrm{O}_{6}\right)$ peak in $\mathrm{BaO}-\mathrm{La}_{2} \mathrm{O}_{3}-\mathrm{B}_{2} \mathrm{O}_{3}$ metaborate glass. ${ }^{16}$ As a result, analogous structural units of $\mathrm{LaBO}_{3}$ and Sr-metaborate are present, and $\mathrm{LaBO}_{3}$ and $\mathrm{SrB}_{2} \mathrm{O}_{4}$ phases evolve.

With the understanding about the SABS glass network connectivity, glass structural unit coordination, and glass thermal stability, SABS glass network evolution process can be described as follows. At zero or low $\mathrm{B}_{2} \mathrm{O}_{3}$ content, $\mathrm{SiO}_{4}$ glass network is highly connected; modifiers and a small amount of $\mathrm{BO}_{3}$ structural units homogeneously distribute within the SABS glass. As $\mathrm{B}_{2} \mathrm{O}_{3}$ content increases, $\mathrm{BO}_{4}$ structural unit content increases but the coordination with $\mathrm{SiO}_{4}$ is rather weak; the $\mathrm{BO}_{3}$ structural units change from metaborate to pentaborate. Substantial $Q^{n}$ structural unit ordering and mixed bonding with the glass modifiers occur. Even though it is not possible to establish exact structure evolution model because of the complexity in bond formation between $\mathrm{B}-\mathrm{O}-\mathrm{Si}, \mathrm{Al}-\mathrm{O}-\mathrm{Si}, \mathrm{B}-\mathrm{O}-\mathrm{Al}$, and modifiers, as well as gradual bond angle change, there is decreased coordination between $\mathrm{SiO}_{4}$ and $\mathrm{BO}_{4}$ structural units. Less connected $\mathrm{BO}_{4}$ structural units interact preferably with the glass modifiers and new, unstable boron-containing crystalline species form.

\section{CONCLUSIONS}

This study is focused on understanding the network connectivity, structural unit local ordering, and thermal stability of SABS glass system. Glass structural units and distribution were analyzed by NMR and Raman spectroscopy. Increasing $\mathrm{B}_{2} \mathrm{O}_{3}$ content causes glass network connectivity to decrease, glass structural unit local ordering, and glass former distribution inhomogeneity. This subsequently degrades SABS glass thermal stability, demonstrated by XRD results after thermal treatment at $850{ }^{\circ} \mathrm{C}$ for different periods of time. Depending on the bonding affinity with glass modifiers, silicon-containing devitrification phases form for low $\mathrm{B}_{2} \mathrm{O}_{3}$ content SABS glasses and boron-containing devitrification phases form for high $\mathrm{B}_{2} \mathrm{O}_{3}$ content SABS glasses. The most desired SABS glass is the $\mathrm{B}_{2} \mathrm{O}_{3}$-free composition, which remains stable after thermal treatment for $200 \mathrm{~h}$ at $850{ }^{\circ} \mathrm{C}$.

\section{ACKNOWLEDGMENTS}

This material is based on work supported by the Department of Energy under Grant No. DE-FC07-06ID14739. The help of Mr. Charles Farley, Department of Geoscience, Virginia Tech during Raman spectroscopy experiment is highly appreciated. The authors also would like to acknowledge Professor Robert Bodnar, Department of Geoscience, Virginia Tech for his suggestions during Raman spectroscopy experiment, and Professor Sabyasachi Sen, Department of Chemical Engineering and Materials Science, University of California, Davis for the NMR experiment.

${ }^{1}$ EG \& G Technical Services, Fuel Cell Hand Book, 7th ed. (US Department of Energy, Office of Fossil Energy, National Energy Technological Laboratory, Morgantown, West Virginia, 2004).

${ }^{2}$ K. L. Ley, M. Krumpelt, R. Kumar, J. H. Meiser, and I. Bloom, J. Mater. Res. 11, 1489 (1996).

${ }^{3}$ M. K. Mahapatra, C. Story, K. Lu, and W. T. Reynolds, Jr., Proceedings of Materials Science and Technology 2007 Conference: Energy: Fuel Cells: Materials, Processing, Manufacturing and Power Management Technologies, edited by P. Singh, A.-M. Azad, D. C. Collins, P. N. Kumta, C. Legzdins, A. Manthiram, A. Manivannan, S. K. Sundaram, and Z. G. Yang, Detroit, Michigan, 16-20 September 2007 (unpublished), p. 371.

${ }^{4}$ M. K. Mahapatra, K. Lu, and W. T. Reynolds, Jr., J. Power Sources 179, 106 (2008).

${ }^{5}$ M. J. Snyder, M. G. Mesko, and J. E. Shelby, J. Non-Cryst. Solids 352, 669 (2006).

${ }^{6}$ S. T. Reis, R. K. Brow, T. Zhang, and P. Jasinski, Ceram. Eng. Sci. Proc. 27, 297 (2006).

${ }^{7}$ W. Vogel, Structure and Crystallization of Glass (Pergamon, New York, 1971), p. 144.

${ }^{8}$ S. Sen, T. Topping, P. Yu, and R. E. Youngman, Phys. Rev. B 75, 094203 (2007).

${ }^{9}$ S. Sen and P. Yu, Phys. Rev. B 72, 132203 (2005)

${ }^{10}$ C. I. Merzbacher, B. L. Sherriff, J. S. Hartman, and W. B. White, J. Non-Cryst. Solids 124, 194 (1990).

${ }^{11}$ L. S. Du and J. F. Stebbins, J. Non-Cryst. Solids 351, 3508 (2005)

${ }^{12}$ B. N. Meera and J. Ramakrishna, J. Non-Cryst. Solids 159, 1 (1993).

${ }^{13}$ P. McMillan, Am. Mineral. 69, 622 (1984).

${ }^{14}$ R. K. Brow and D. R. Tallant, J. Non-Cryst. Solids 222, 396 (1997).

${ }^{15}$ P. Boolchand, M. Jin, D. I. Novita, and S. Chakravarty, J. Raman Spectrosc. 38, 660 (2007).

${ }^{16}$ S. A. Brawer and W. B. White, J. Non-Cryst. Solids 23, 261 (1977).

${ }^{17}$ E. I. Kamitsos, J. A. Kapoutsis, H. Jain, and C. H. Hsieh, J. Non-Cryst. Solids 171, 31 (1994)

${ }^{18}$ A. K. Hassan, L. M. Torell, L. Börjesson, and H. Doweidar, Phys. Rev. B 45, 12797 (1992).

${ }^{19}$ B. O. Mysen, L. W. Finger, D. Virgo, and F. A. Seifert, Am. Mineral. 67, 686 (1982) 
${ }^{20} \mathrm{H}$. Li, P. Hrma, J. D. Vienna, M. Qian, Y. Su, and D. E. Smith, J. NonCryst. Solids 331, 202 (2003).

${ }^{21}$ L. S. Du and J. F. Stebbins, J. Non-Cryst. Solids 315, 239 (2003).

${ }^{22}$ W. J. Dell, P. J. Bray, and S. Z. Xiao, J. Non-Cryst. Solids 58, 1 (1983).

${ }^{23}$ S. Kroeker and J. F. Stebbins, Inorg. Chem. 40, 6239 (2001).

${ }^{24}$ R. Martens and W. Müller-Warmuth, J. Non-Cryst. Solids 265, 167 (2000).

${ }^{25}$ B. C. Bunker, D. R. Tallant, R. J. Kirkpatrick, and G. L. Turner, Phys. Chem. Glasses 31, 30 (1990).

${ }^{26}$ R. K. Brow, D. R. Tallant, and G. L. Turner, J. Am. Ceram. Soc. 79, 2410 (1996).

${ }^{27}$ N. Ollier, T. Charpentier, B. Boizot, G. Wallez, and D. Ghaleb, J. NonCryst. Solids 341, 26 (2004).

${ }^{28}$ F. L. Galeener, Phys. Rev. B 19, 4292 (1979).
${ }^{29}$ F. Seifert, B. O. Mysen, and D. Virgo, Am. Mineral. 67, 696 (1982).

${ }^{30}$ B. O. Mysen, D. Virgo, and F. A. Seifert, Am. Mineral. 70, 88 (1985).

${ }^{31}$ J. E. Shelby, Introduction to Glass Science and Technology (Royal Society of Chemistry, Cambridge, 2005).

${ }^{32}$ M. B. Volf, Chemical Approaches to Glass: Glass Science and Technology (Elsevier, Amsterdam, 1984), Vol. 7, p. 100.

${ }^{33}$ H. Scholze, Glass Nature, Structure and Properties (Springer-Verlag, New York, 1991), p. 109.

${ }^{34}$ L. S. Du and J. F. Stebbins, J. Phys. Chem. B 107, 10063 (2003).

${ }^{35}$ W. F. Du, K. Kuraoka, T. Akai, and T. Yazawa, J. Phys. Chem. B 105, 11949 (2001).

${ }^{36}$ S. K. Lee, B. O. Mysen, and G. D. Cody, Phys. Rev. B 68, 214206 (2003).

${ }^{37}$ A. J. G. Ellison and P. C. Hess, J. Non-Cryst. Solids 127, 247 (1991). 